\section{Revista de Historia Económica}

Journal of Iberian and Latin American Economic History

Published for Instituto Figuerola de Historia y Ciencias Sociales, Universidad Carlos III de Madrid

\section{Chief Editor}

Blanca Sánchez Alonso, Universidad CEU-San Pablo, Madrid, Spain Co-editors

Sandra Kuntz Ficker, El Colegio de México, Mexic

William Summerhill, UCLA, USA

Revista de Historia Económica - Journal of Iberian and Latin American Economic History (RHE-JILAEH) welcomes contributions with comparative approaches, especially those that include a wide geographical or global coverage. The journal will promote the presentation of new topics, ideas and perspectives from the different social sciences, notably new historical and economic methods. RHE-JILAEH publishes original research papers on economic history, economic thought and all those areas of economics concerned with long-term analysis. The geographical area addressed in these papers should preferably cover Spanish and Portuguese speaking countries and wider areas including any of these countries.

RHE-JILAEH is pleased to announce that it has been ranked 14th out of 69 journals in the history category, with an impact factor of 0.545 in the latest (2012) Thomson-Reuters Journal Citation Report ${ }^{\circ}$. We are also indexed in the History of Social Science category, as well as in History and Economics.

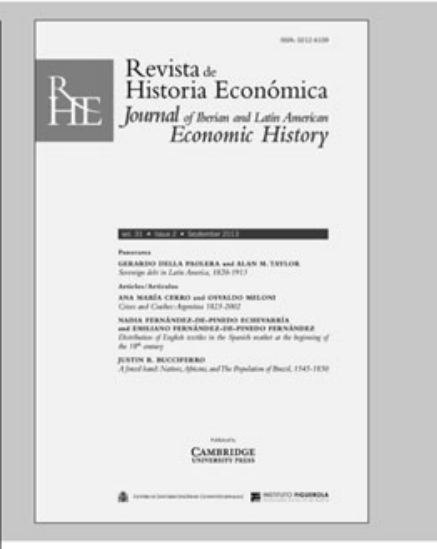

Revista de Historia Económica is available online at: http://journals.cambridge.org/rhe

\section{To subscribe contact}

Customer Services

\section{Americas:}

Phone +1 (845) 3537500

$\mathrm{Fax}+1(845) 3534141$

Email

subscriptions_newyork@cambridge.org

\section{Rest of world:}

Phone $+44(0) 1223326070$

$\mathrm{Fax}+44(0) 1223325150$

Email journals@cambridge.org

\section{Free email alerts}

Keep up-to-date with new material - sign up at

journals.cambridge.org/register 


\section{INSTRUCTIONS FOR CONTRIBUTORS}

\section{Editorial policy}

Financial History Review, published by Cambridge University Press on behalf of the European Association for Banking and Financial History e.V., is committed to high international scholarly standards and invites scholars doing research on banking, financial and monetary history to submit papers on any subject, historical period and regional area. The Review deliberately seeks to embrace a broad approach to publishing research findings within this growing historical specialism. Articles can address banking, financial and monetary history from different perspectives, including theoretically inspired approaches, advanced empirical analysis, and the interrelations between history, finance, policy, culture and society. The Review particularly encourages submissions from young scholars.

Articles should normally be of 8,000 words including footnotes, tables and any graphical or other illustrative material (a graph occupying an A4 page is deemed equivalent to 300 words).

The journal is published in English and contributions should be submitted in that language. Authors whose native language is other than English are encouraged to send their manuscripts to a professional native translator for a preliminary revision prior to submission.

\section{Submissions}

Manuscripts can be submitted through the new online submission facility available on the Review's web page: http://journals.cambridge.org/FHR Authors are required to upload:

- a cover page with title, author(s)' name and affiliation, and full contacts of the corresponding author (email and postal address, telephone, fax, web page);

- a blinded copy of the manuscript. The cover page of the document should include: the paper's title, a short abstract (max. 200 words), a short list of keywords ( $\max .4$ ), and JEL codes. Please note that you should supply a WORD or RTF document for the main text body (including footnotes, bibliographical references, appendices) and a different single document in PDF for Tables and Figures.

Submission of a paper will be taken to imply that it is unpublished (even in a language other than English) and is not being considered for publication elsewhere. Upon acceptance of a paper, the author will be asked to assign copyright (on certain conditions) to the European Association for Banking and Financial History e.V.

Contributors are responsible for obtaining permission to reproduce any material in which they do not own copyright, to be used in both print and electronic media, and for ensuring that the appropriate acknowledgements are included in their manuscript.

\section{Preparation of manuscripts}

I. Manuscripts should be typed double spaced throughout on A4, i.e. $29 \mathrm{~cm}$ x 2 I cm., or II" x 8 ". Wide margins should be left on all sides.

2. Pages should be numbered consecutively, beginning with the title page, the page number being placed, ideally, at the top right-hand corner of the page.

3. Footnotes should be typed, double-spaced, numbered consecutively and be grouped together at the end of the manuscript. Footnotes will appear in the journal at the bottom of each printed page. Footnotes should solely be concerned with matters of source citation. Substantive footnotes, involving commentary or argument, should be avoided, such material being more properly contained within the body of the text. If an elaborate commentary on sources is required, and cannot be incorporated within the body of the article, it should form an appendix to the article (to be included in the total extent of 8,000$)$.

4. Articles may, if appropriate, be divided into subsections designated by Roman numerals centred on the page. Sub-headings within an article should be avoided.

5. Tables, maps and figures should be submitted on separate pages and grouped together in a section at the end of the manuscript. Please number tables/maps/figures consecutively with Arabic numerals, using that reference within the text, e.g. Table I, Map 5, Figure 24. Their appropriate position in the body of the text should be indicated in the text as \{please place Table I near here\}.

6. Contributors should follow exactly the stylistic conventions, set out below, when writing the final version of their articles. Copy-editing is tedious and time-consuming and, as a consequence, the Editors reserve the right to return a contribution accepted for publication solely on the grounds that it does not follow the conventions.

\section{Conventions}

I. Spelling British spelling is preferred, using -ise in words with alternative -ise/ize. However, American spelling will be accepted.

2. Foreign words or phrases in an English sentence should be underlined (for italic), except for proper names, or quotations or words in common usage.

3. Quotations: follow the punctuation, capitalisation and spelling of the original source. Within the body of the text of an article, a quotation should begin, and end, with single quotation marks, with double quotation marks only used for quotations within quotations. Quotations of more than about 50 words should be broken off from the body of the text, by being indented from the left-hand margin as a separate block of text, without quotation marks. Extensive quotations from non-English language sources should be translated into English in the text and (if necessary) the original text supplied in a footnote.

4. Numbers: spell out numbers up to ten, but use Arabic numerals thereafter and standard contractions, as with $m$ for million. Spans of numbers should be elided to the smallest unit, e.g. 4I-2, I95-8, 2I6-I8. Percentages should be given in figures, with the words 'per cent' spelled out, e.g. 5 per cent; the sign \% should be used in footnotes and tables. Standard fractions can be used as numbers.

5. Dates: use Io December I948 in the text, I930s (not I930's), and the twentieth century (not the 2oth century, or C20th). Dates should be contracted in the footnotes, hence Io Dec. I948.

6. Ellipsis whether within, or at the end of, a sentence should be indicated by three spaced full stops.

7. References: Bibliographical references should appear at the end of the manuscript after the footnotes, listed by surname of author (in capital letters) in alphabetical order. If more than one text by the same author(s) is cited for a particular year, then the works should be distinguished by a letter, e.g. Levine (I997a) and Levine (I997b). References are limited to the works cited in the manuscript. Please adopt the following style:

SCHNABEL, I. (2004). The German twin crisis of 193I. The Journal of Economic History, 64, pp. 822-7I

RAJAN, R. and ZINGALES, L. (2003). The Great Reversal: the politics of financial development in the 20th century. Journal of Financial Economics, 69, pp. $5-50$

ACCOMINOTTI, O., FLANDREAU, M., REZZIK, R. and ZUMER, F. (20I0). Black man's burden, white man's welfare: control, devolution and development of the British Empire, I880-I9I4. European Review of Economic History, I4, pp. 47-70

CALOMIRIS, C. (2000). U.S. Bank Deregulation in Historical Perspective. Cambridge: Cambridge University Press.

PREVEZER, M. and RICKETTS, M. (I999). Corporate governance: the UK compared with Germany and Japan. In N. Dimsdale and M. Prevezer (eds.), Capital Markets and Corporate Governance. Oxford: Oxford University Press.

References should be included in the body of the text in abbreviated form and within parenthesis, i.e.

(Schnabel 2004, pp. 824-5)

(Rajan and Zingales 2003 , p. 3I)

(Accominotti et al. 20I0, pp. 58-9)

8. Sources. If the paper includes extensive references to primary sources such as archives, statistics, periodicals, yearbook and documentary sources, these should appear in a separate section under an additional 'Sources' heading, with full references, i.e.

The Economist

Salings Börsenjahrbuch I9I0-II (Berlin, I9II)

International Monetary Funds, International Financial Statistics (Washington DC)

Public Record Office, Kew, London: Colonial Office Papers

9. Footnotes. All notes are to be included as footnotes and numbered in ascending order of appearance in Arabic numbers as superscript after the full stop at the end of the sentence.

References to archival sources must include the name and location of the collection, and the file where the document can be found. In general, citations should follow accepted national styles, always giving an extended version for the first document cited from a source, e.g.

International Monetary Funds, International Financial Statistics [henceforth IMF, IFS];

Public Record Office [henceforth PRO]: Colonial Office Papers [henceforth CO]; 20I/6I4, pp. 87-IOI, III-24, and CO 309/I39, pp. I5O-6, dispatches and minutes, 8 May to I3 Jun. I893

10. Tables and graphs. Tables, graphs, and maps should be original. They should include a short title, be numbered in order of appearance and provide details of the corresponding sources.

Proofs

Typographical or factual errors only may be changed at proof stage. The publisher reserves the right to charge authors for correction of non-typographical errors.

\section{Offprints}

Authors will receive a PDF offprint of their published article. 


\section{VOLUME 22 - PART 1 - APRIL 2015}

\section{Financial History Review}

\section{Contents}

The past mirror: notes, surveys, debates

Xavier De Scheemaekere, Kim Oosterlinck and Ariane Szafarz

Identifying economic crises: insights from history

\section{Articles}

Anne L. Murphy

'Writes a fair hand and appears to be well qualified': the recruitment

of Bank of England clerks, 1800-1815

Sung Won Kang and Hugh Rockoff

Capitalizing patriotism: the Liberty loans of World War I

Sebastian Alvarez

The Mexican debt crisis redux: international interbank markets and

financial crisis, 1977-1982

Eliezer Z. Prisman

Real estate transactions in ancient Israel: excavating embedded options utilizing modern finance

Cambridge Journals Online

For further information about this journal please go to the journal web site at: journals.cambridge.org/fhr

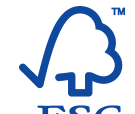

FSC

www.fsc.org
CAMBRIDGE UNIVERSITY PRESS 